\title{
SOEP
}

SOEPpapers

on Multidisciplinary Panel Data Research
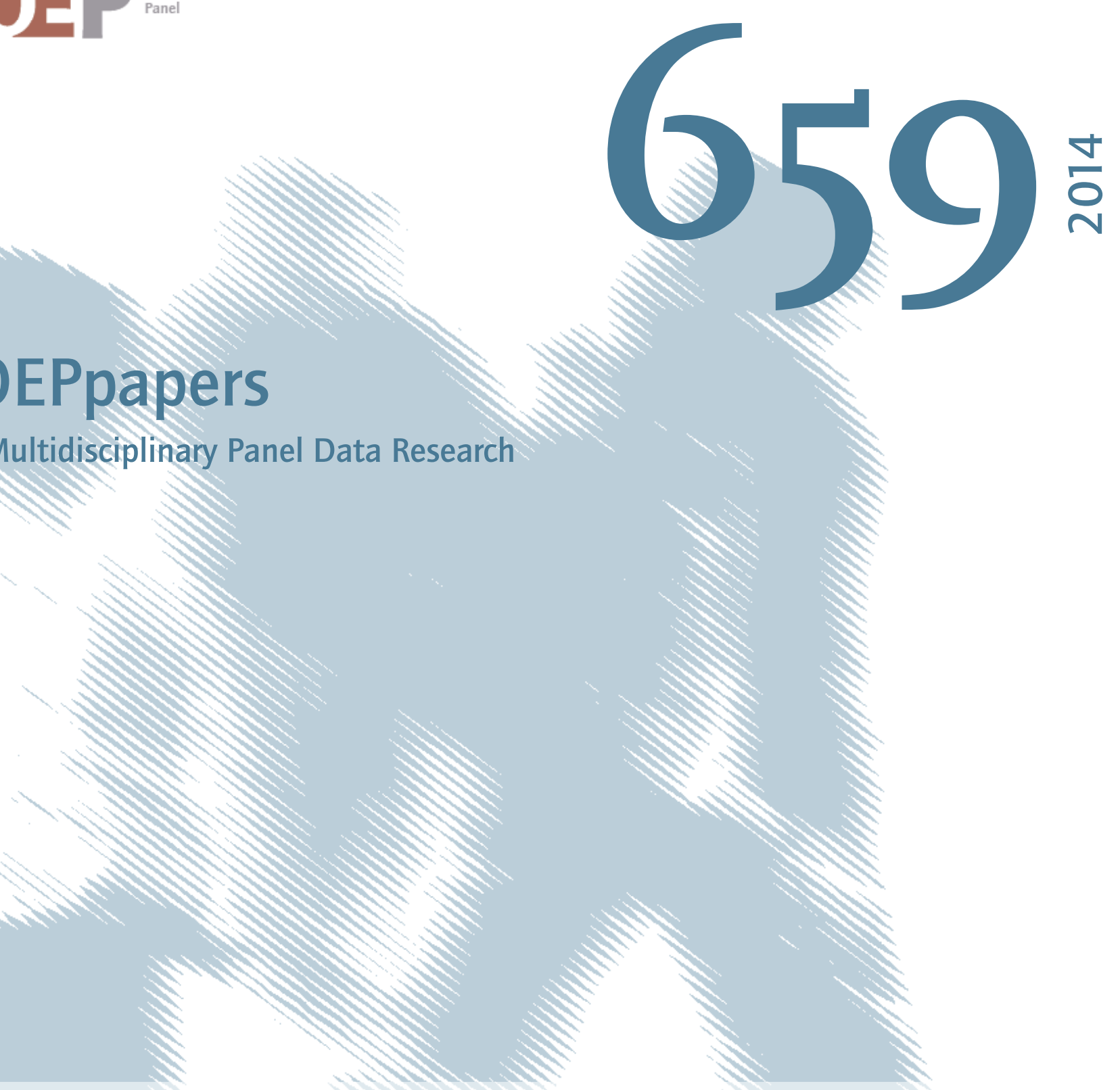

\section{Culture, Spatial Diffusion of Ideas and their Long-Lasting Imprints - Evidence from Froebel's Kindergarten Movement}




\section{SOEPpapers on Multidisciplinary Panel Data Research}

at DIW Berlin

This series presents research findings based either directly on data from the German SocioEconomic Panel Study (SOEP) or using SOEP data as part of an internationally comparable data set (e.g. CNEF, ECHP, LIS, LWS, CHER/PACO). SOEP is a truly multidisciplinary household panel study covering a wide range of social and behavioral sciences: economics, sociology, psychology, survey methodology, econometrics and applied statistics, educational science, political science, public health, behavioral genetics, demography, geography, and sport science.

The decision to publish a submission in SOEPpapers is made by a board of editors chosen by the DIW Berlin to represent the wide range of disciplines covered by SOEP. There is no external referee process and papers are either accepted or rejected without revision. Papers appear in this series as works in progress and may also appear elsewhere. They often represent preliminary studies and are circulated to encourage discussion. Citation of such a paper should account for its provisional character. A revised version may be requested from the author directly.

Any opinions expressed in this series are those of the author(s) and not those of DIW Berlin. Research disseminated by DIW Berlin may include views on public policy issues, but the institute itself takes no institutional policy positions.

The SOEPpapers are available at

http://www.diw.de/soeppapers

\section{Editors:}

Jürgen Schupp (Sociology)

Gert G. Wagner (Social Sciences, Vice Dean DIW Graduate Center)

Conchita D'Ambrosio (Public Economics)

Denis Gerstorf (Psychology, DIW Research Director)

Elke Holst (Gender Studies, DIW Research Director)

Frauke Kreuter (Survey Methodology, DIW Research Professor)

Martin Kroh (Political Science and Survey Methodology)

Frieder R. Lang (Psychology, DIW Research Professor)

Henning Lohmann (Sociology, DIW Research Professor)

Jörg-Peter Schräpler (Survey Methodology, DIW Research Professor)

Thomas Siedler (Empirical Economics)

C. Katharina Spieß (Empirical Economics and Educational Science)

ISSN: 1864-6689 (online)

German Socio-Economic Panel Study (SOEP)

DIW Berlin

Mohrenstrasse 58

10117 Berlin, Germany

Contact: Uta Rahmann | soeppapers@diw.de 


\title{
Culture, Spatial Diffusion of Ideas and their Long- Lasting Imprints - Evidence from Froebel's Kindergarten Movement
}

\author{
Stefan Bauernschuster ${ }^{\ddagger}$ and Oliver Falck ${ }^{*}$
}

This version: March 2014

\begin{abstract}
We document the spatial diffusion of Friedrich Froebel's radical invention of kindergartens in $19^{\text {th }}$-century Germany. The first kindergarten was founded at Froebel's birthplace. Early spatial diffusion can be explained by cultural proximity, measured by historical dialect similarity, to Froebel's birthplace. This result is robust to the inclusion of higher order polynomials in geographic distance and similarity measures with respect to industry, geography or religion. Our findings suggest that a common cultural basis facilitates the spillover of ideas. We further show that the contemporaneous spatial pattern of child care coverage is still correlated with cultural similarity to Froebel's place of birth.
\end{abstract}

Keywords: culture, spatial diffusion, public child care

JEL Codes: N33; J13; Z13

‡ Department of Business Administration and Economics, University of Passau, Innstr. 27, D94032 Passau (Germany), Phone: +49 851509 2540, Email: stefan.bauernschuster@unipassau.de, Ifo Institute - Leibniz Institute for Economic Research at the University of Munich, and CESifo.

* Ifo Institute - Leibniz Institute for Economic Research at the University of Munich, Poschingerstr. 5, D-81679 Munich (Germany), Phone: +49 899224 1370, Email: falck@ifo.de, CESifo, and Ludwig-Maximilians-University of Munich.

Acknowledgments: We are indebted to Felix Höschle, Katrin Huber, Natalie Obergruber, and Helen Zeidler for excellent research assistance. 


\section{Introduction}

Economists often refer to the spatial diffusion of new technologies and ideas as resembling the propagation of a wave caused by a stone thrown into the water. Accordingly, a new technology or idea is first adopted in locations which are close to the place of invention. With increasing distance adoption slows down. This pattern has been shown among others for the diffusion of Protestantism (Becker and Woessmann, 2009; Cantoni, 2012), the printing press (Dittmar, 2011) and many other major technologies (Comin et al., 2012).

The reasons brought forward for this pattern are various and have to do with the fact that many forms of social interactions such as migration, personal contacts during visits or trade decline with distance. So in the end, concentric geographic distance circles around the place of invention are only a rough proxy for many factors that are relevant in the spatial diffusion of new technologies and ideas. Apart from purely distance related factors, cultural proximity to the place of invention seems to play an important role in the diffusion process. However, the problem is that it is hard to find measures of cultural proximity which go beyond geographic distance.

We use historical dialect data to capture cultural proximity net of geographic distance and study the spatial diffusion of the 'kindergarten' idea in Germany. In the early $19^{\text {th }}$ century, pre-school institutions were dominated by institutions where children at a minimum age of two could virtually be "stored" without any pedagogical or educational aims. In this context, Friedrich Froebel came up with his radical new idea of pre-school educational institutions. Froebel established his first institution close to his place of birth in Bad Blankenburg, Thuringia, in 1839. He chose the name "kindergarten" for his institution because it should be like a garden (German "Garten") where experienced gardeners in harmony with nature should cherish children (German "Kinder") like small plants. This idea soon diffused across Germany mainly through personal contacts with Froebel or his disciples.

The dialect data we use to measure cultural proximity stem from an encompassing language survey conducted by the linguist Georg Wenker between 1879 and 1888 . These data have been introduced in the economic literature by Falck et al. (2012), who show at length that the historical dialect data give a unique opportunity to comprehensively measure cultural differences across German regions. These authors provide evidence that dialect similarity comprehensively stores information about historical interactions across the German regions 
beyond what a huge set of similarity measures including a common institutional and religious background, industry similarity, geographic distance and similarity with respects to many several other geographic regional characteristics would predict. We thus take a broad and evolutionary perspective of culture which is similar to that of Guiso et al. (2006), who define culture as "those customary beliefs and values that ethnic, religious, and social groups transmit fairly unchanged from generation to generation." We combine these data with information about the location of Froebel kindergarten openings between 1834 and 1905 as well as with rich contemporaneous county-level data on public child care coverage rates and individual (mother)-level data on child care attendance.

We start our quest for the relevance of cultural proximity for the diffusion of ideas by explaining the spatial diffusion pattern of Froebel kindergartens within Germany at the end of the $19^{\text {th }}$ and beginning $20^{\text {th }}$ century by dialect similarity to Froebel's place of activity. We find that, even conditional on geographic distance, higher order polynomials in geographic distance and similarity measures with respect to industry, geography or religion, dialect similarity to Froebel's place of activity can explain the spatial distribution of Froebel kindergartens between 1843 and 1905. In order to provide evidence for the validity of our empirical approach, we show that dialect similarity to Froebel's place of activity is not correlated with variables such as historical population density, city growth or the founding year of the first library. These results further corroborate our idea that cultural proximity to Froebel's place of activity was exogenous to other potential determinants of child care. Thus, our results are compatible with the hypothesis that ideas spill over through social interaction; and that social interaction needs a common basis, namely a common culture.

We next proceed to child care coverage in West Germany at the end of the $20^{\text {th }}$ and start of the $21^{\text {st }}$ century. In the 1990 s and 2000s, West Germany was still far away from universal public child care coverage so that we observe substantial regional variation. Our aim is to test whether the spatial diffusion of the kindergarten movement in the $19^{\text {th }}$ century and thus early experience with pedagogical-oriented child care institutions has left long-lasting imprints. This might be because of intergenerational transmission of attitudes towards public child care or longevity of child care institutions. We indeed find that counties which are culturally more similar to Froebel's place of activity have higher public child care coverage rates in the 1990 s and 2000 s. This result is robust to the inclusion of a large set of county-level control variables. To make sure that migration from East Germany to West 
German counties does not confound our estimates, we employ two strategies: first, we control for a county's dialect similarity and geographic distance to all other East German counties to capture East-West migration potential; second, we also control for the number of a county's inhabitants that fled from the Soviet occupation zone to capture East-West migration before the Berlin Wall was erected. Our finding is unaffected by this specification. Moreover, we find that dialect similarity to other East German counties is, if at all, negatively correlated with public child care coverage. This provides further evidence that it is not the cultural proximity to East Germany as such that drives our results but indeed the specific cultural proximity to Froebel's place of activity. Finally, we show that our results are also found using individual-level data from the German Socio-Economic Panel (SOEP).

The remainder of the paper is organized as follows. Section 2 gives detailed background information on Froebel's kindergarten movement. Section 3 introduces our historical data on dialects as well as historical and recent data on child care in Germany. Section 4 presents our empirical results on the relevance of cultural proximity to Froebel's ideas for the prevalence of child care institutions from the $19^{\text {th }}$ century until today. Section 5 concludes.

\section{Historical Background}

\subsection{Froebel's innovative approach to child care}

At the end of the $18^{\text {th }}$ century, the so-called "Bewahranstalt" was the only established daycare facility for children at pre-school age in the territory which should later become Germany. The name "Bewahranstalt" already suggests that it was mainly an institution where children at a minimum age of two could virtually be "stored", often for 12 hours a day. A "Bewahranstalt" was mostly located in one big room with one person to look after the children. Hygiene played a big role due to childhood diseases and other illnesses. In most institutions children were also offered a simple warm meal at lunchtime. However, the childminder was not specially trained for her job and her only aim was to keep the children quiet rather than support their development and socialisation (Konrad, 2004). As such, a "Bewahranstalt" was not a well-accepted child care institution supporting child development but merely a lender of last resort for lower class women who could not always care for their 
children on their own, such as day-laborers, prostitutes, or field workers. Typically, a "Bewahranstalt" was completely publicly funded. ${ }^{1}$

The real peculiarity of the development of child care facilities in Germany was the establishment of so-called "kindergartens", a name coined by their inventor Friedrich Froebel. These "kindergartens" should not be mere "storage" institutions for children of disadvantaged women but pedagogical child care centers where fostering children's development was at the core of the whole concept. The name "kindergarten" was chosen by Froebel because this child care institution should be like a garden (German "Garten") where experienced gardeners in harmony with nature should cherish children (German "Kinder") like small plants. Additionally, there was always a virtual garden attached to the building of the day-care facilities so that children could spend time in nature (Konrad, 2004). As such, Froebel's educational approach stood in clear contrast to the prevailing view at that time that children were inherently sinful and that their will must therefore be broken in order to educate them (Wollons, 2000).

Friedrich Froebel was born in the tiny village Oberweissbach, Thuringia, in 1782. In 1805, Froebel became employed as a teacher in a reform school in Frankfurt. It was then when he started to study the ideas of the Swiss pedagogue Pestalozzi (1746-1827). In the following years, Froebel visited Pestalozzi twice at his famous institute for education in Switzerland and even spent two years there. After fighting in the anti-Napoleonic wars, he returned to Thuringia as he felt obliged to care for his three nephews who had lost their father. In 1831, he moved to Switzerland where he became head of an elementary school and an orphanage. There, Froebel developed his revolutionary idea of a pre-school education for children. He wanted to establish maternal education methods which should support children in their development, for example by using songs and pictures. In order to realise this idea, Froebel gave up his job in Switzerland and moved back to his roots in Thuringia where, in 1839, he founded the first kindergarten in Bad Blankenburg (Konrad, 2004) and, in the following year, the second one in nearby Rudolstadt (Weiland, 1983). Both places are situated in today's county Saalfeld-Rudolstadt, Thuringia. Eventually, the diffusion of Froebel's kindergarten idea originated from his place of birth which he rather chose for the first kindergarten

\footnotetext{
${ }^{1}$ Infant schools for three to seven year olds were established in the early 19 th century. Funded mostly by the church and charities, these infant schools had clear educational targets. Yet, just as "Bewahranstalten", they were mainly offered to and drawn on by poor and needy families.
} 
foundation for private than for professional reasons. We thus argue that Frobel's place of birth is an as-good-as-random starting place.

\subsection{The spread of Froebel's kindergartens during the $19^{\text {th }}$ century}

By 1847, seven kindergartens applying Froebel's methods had been built up in Germany. Apart from the kindergartens, Friedrich Froebel also established a seminar to educate kindergarten teachers in Bad Liebenstein, which lies in today's Wartburgkreis, the neighboring county of Saalfeld-Rudolstadt. Ida Seele, arguably Froebel's favourite student, soon became known as the first "Kindergaertnerin" (kindergarten teacher) worldwide. However, in 1851, Karl Otto von Raumer, minister of education and the arts in Prussia, banned kindergartens by law. Raumer referred to the "destructive tendencies" [of kindergartens] with respect to religion and politics" and claimed that the kindergarten was part of a conspiracy, a socialistic system, which wanted to educate children to atheism. The ban of kindergartens lasted for nine years; this was not enough to stifle the movement.

Further on, the spread of kindergartens and kindergarten teacher institutes in Germany mainly worked through personal contacts with Froebel or his disciples and through the foundation of societies. By 1877, twenty kindergarten teacher training institutes had been established, the most famous one by Friedrich Froebel's grandniece Henriette Breymann in Berlin. The institute was called Pestalozzi-Froebel House and not only included a training institute but also a kindergarten. Educators from all over the world visited and studied at the Pestalozzi-Froebel House (Allen, 2000).

Particularly important in the diffusion of the kindergarten idea was the German Froebel Society ("Deutscher Froebelverband" - DFV) which did a lot of determined lobbying in favour of the kindergarten (Konrad, 2004). From 1859 on, this association planned the expansion of the kindergarten starting from Froebel's home county Saalfeld-Rudolstadt (Thuringia) and offered conferences for kindergarten teachers as well as public exhibitions where people could get in touch with Froebel's methods. In 1895, the association published a general course of instruction for kindergartens, which was a shining example for public pre-school education. When in the 1910 s public and communal child teacher seminars were founded, Froebel pedagogics were an integral part of it (Konrad, 2004). Froebel societies also played an important role in funding the kindergartens. They raised money from 
membership fees, donations, charity events, testamentary donations and the so-called "Spendenbuechse" (= donation box) which was located in the institutions and interested visitors were quietly asked for a donation.

In the $19^{\text {th }}$ and early $20^{\text {th }}$ century, Froebel kindergartens constituted still a minority of child care institutions. Political and religious conservatives often opposed the kindergarten movement, amongst others because the women's movement discovered the occupation of a kindergarten teacher as a means to foster women's economic independence (Allen, 1988). Indeed, Helene Lange, Auguste Schmidt, and Marie Loeper-Housselle - three protagonists of the first wave of the women's movement in Germany - intensively studied the work of Friedrich Froebel. Subsequently, they founded the German female teacher association (Allgemeinen Deutschen Lehrerinnen Verein (ADLV)) in Friedrichroda (Thuringa) in 1890, and Marie Loeper-Housselle founded the first Froebel-kindergarten in Alsace in 1862 (Artaria, 1894).

\subsection{Froebel's ideas in the course of the $20^{\text {th }}$ century}

During the Nazi regime Froebel's kindergarten movement experienced another setback. Kindergartens in Froebel's sense were condemned during the Nazi regime because they encouraged "softness, sensitivity, and intellectual precocity" (Allen, 2000); this stood in contrast to the idea of the Nazi regime to "raise a hardened generation - strong, reliable, obedient and decent" (Benzing, 1941, quoted by Allen, 2000). Only after World War II, the original ideas of Froebel and the true value of kindergartens were gradually rediscovered (Allen, 2000). Already in 1946, kindergartens were officially included into the educational system as a "pre-school institution" by the East German School Law. As a consequence, we saw a massive expansion of kindergartens in East Germany. However, this expansion was largely motivated by the intention of the socialist regime to indoctrinate children already very early in life with the socialist propaganda. In West Germany, the idea of having universal public kindergartens was long resisted by conservatives who argued that the family "should not be relieved of its primary responsibility" by such a system (Soziographisches Institut, 1962, quoted by Allen, 2000). This view went hand in hand with policies that rather supported the traditional male breadwinner model. However, from the 1970s at the latest, kindergartens have become a well-accepted part of the educational system also in West 
Germany (Allen, 2000). Today, the value of public child care is undisputed and the argument that public child care can foster children's development is prevalent in virtually all discussions on public child care and early childhood education.

\section{Data}

\subsection{Data on cultural proximity to Saalfeld-Rudolstadt}

First, we would like to address the question whether proximity to Froebel's ideas can explain the spatial diffusion pattern of the first kindergartens within Germany at the end of the $19^{\text {th }}$ and beginning of the $20^{\text {th }}$ century. In order to address this question, we need a variable measuring how intensely a region was connected to Saalfeld-Rudolstadt, Froebel's place of activity, in the early $19^{\text {th }}$ century. The more intense the contact to Saalfeld-Rudolstadt, the more likely a region should have got acquainted with Froebel's ideas. Let us define this connectedness between regions, which might have gradually emerged over centuries and is therefore deeply rooted in history, as cultural similarity (Guiso et al., 2009). Our measure of cultural proximity to Froebel is based on extraordinarily rich historical dialect data from the $19^{\text {th }}$ century which have been introduced into the economic literature by Falck et al. (2012) and have already been used by Bauernschuster et al. (2014). As is discussed at length in Falck et al. (2012), dialects are the outcomes of an evolutionary process and store-almost like a genome-information about historical interactions that occurred over centuries in the area of today's Germany. Common religious history, political borders, unique historical events, previous mass migration waves, etc., all left some long-lasting imprints on local dialects structures. A higher degree of dialect similarity between any two regions indicates that those regions had more intensive interaction in the past resulting in a common culture (Michalopoulos 2012). And this is exactly what we would like to have when it comes to measuring cultural proximity to Froebel.

Our unique linguistic data were collected in a comprehensive language survey conducted by the linguist Georg Wenker between 1879 and $1888 .^{2}$ The survey was intended to be an indepth investigation of language variation within the newly created German Empire. At the time the survey was conducted, a standardized national language (Hochdeutsch) had not yet

\footnotetext{
${ }^{2}$ See Lameli (2013) for more details.
} 
become prevalent; in fact, people even from neighboring villages sometimes were not able to properly communicate with each other. The survey asked pupils to read 40 German sentences, designed to reveal specific linguistic features, in their local dialect. In an extensive evaluation process, linguists have determined 66 prototypical characteristics that are most relevant for structuring the German language area. These characteristics have to do with the pronunciation of consonants and vowels as well as with grammar. These 66 characteristics are matched to Germany's current administrative classification scheme to quantify each region's dialect and to construct a dialect similarity matrix across all 439 regions.

Using these historical dialect data, we compute a variable which, for each and every county of Germany, depicts the dialect similarity to Saalfeld-Rudolstadt, Froebel's place of activity. Figure 1 presents a graphical overview of the emerging pattern. As expected, we see that geographic distance plays an important role for dialect similarity between SaalfeldRudolstadt and a specific county. However, it also becomes evident that there is far more to our dialect measure than mere geographic distance. This can also be seen from Table 1, which shows the results of a regression using dialect similarity $s_{i S L F}$ of a specific county $i$ to Saalfeld-Rudolstadt $(S L F)$ as the outcome variable and geographic distance $d_{i S L F}$ of a specific county $i$ to Saalfeld-Rudolstadt ( $S L F)$ (and its square) as the explanatory variable(s):

$$
s_{i S L F}=\alpha+\beta d_{i S L F}+\delta d_{i S L F}^{2}+\varepsilon_{i S L F}
$$

As expected, geographic distance and dialect similarity are negatively correlated. However, the $R^{2}$ suggests that geographic distance only explains about 47 percent of the total variance in dialect similarity.

Table 1: Correlations between dialect similarity and geographic distance

Dialect similarity to SLR

(1)

$-0.703^{* * *}$

(0.030)

Geographic distance to SLF ${ }^{2}$
(2)

$-0.997^{* * *}$

(0.129)

$0.006^{* *}$

(0.003)

\begin{tabular}{lcc}
\hline $\mathrm{N}$ & 439 & 439 \\
$\mathrm{R}^{2}$ & 0.465 & 0.470
\end{tabular}

Note: The table shows results of OLS regressions; robust standard errors in parentheses. $* * * 1 \%$ level of significance, ** $5 \%$ level of significance, * $10 \%$ level of significance. 


\subsection{Data on the development of child care in Germany}

We merge our historical dialect data to different regional data sets covering information on the prevalence of child care from the $19^{\text {th }}$ century until present days. The first historical child care data set provides information on the very first Froebel kindergartens in Germany. We have collected information on the existence of Froebel kindergartens in the years 1843 to 1905 from reports and personal letters by Friedrich Froebel as well as from early issues of the journal "Kindergarten" published by the German Froebel Society. In particular, in his report "Nachricht und Rechenschaft von dem Deutschen Kindergarten" from 1843, Friedrich Froebel mentions existing child care institutions employing his pedagogical concepts in Blankenburg, Dresden, Frankfurt, Gera, Rudolstadt, Hildburghausen, Coburg, and Breslau (see Lange 1862, p.478 as quoted in Heiland 1997). In a personal letter to August Haerter from 28 February 1847, Froebel refers to kindergartens in Dresden, Frankfurt, Gera, Annaburg, Quetz, Gotha, Homburg vor der Hoehe, and Luenen. Additionally, there were child care institutions applying Froebel ideas in Darmstadt and Hildburghausen (Heiland 1997). In his letter to Karoline Luise von Schwarzburg-Rudolstadt from 30 April 1847, Friedrich Froebel alludes to kindergartens in Hildburghausen, Darmstadt, Homburg vor der Hoehe, Frankfurt, Gotha, Annaburg, Quetz, Luenen, Dresden, Milau, and Darmstadt (Heiland 1997). Apart from these reports and personal letters by Friedrich Froebel, we use data from the "Statistik der Froebelschen Anstalten im Deutschen Reiche" published in the 1895 and 1905 issues of the journal "Kindergarten". As explicitly mentioned in the magazine "Kindergarten" (vol. 5, 1895, p. 65), this data collection is the first attempt to systematically gather information on Froebel institutions in Germany. We assign each place for which we identified an early Froebel kindergarten to the county the place is located. This allows us to merge these Froebel kindergarten data to our dialect data on the county level. A graphical overview of the distribution of early Froebel kindergartens across Germany is presented in Figure 1.

The second question we would like to address is whether the spatial diffusion of the kindergarten movement in the $19^{\text {th }}$ century and thus early experience with pedagogicaloriented child care institutions has left long-lasting imprints. In other words, we test whether proximity to Froebel's ideas can still explain public child care coverage at the end of the $20^{\text {th }}$ and the beginning of the $21^{\text {st }}$ century. To investigate this second research question, we draw on information about public child care coverage for children at kindergarten age (i.e., aged 
three to six) on the county level in 1994. We have exact county-level data on the number of public child care slots from the Statistical Offices of the German Laender. At the same time, the Statistical Offices of the German Laender also publish data on the number of children aged three to six in each county. This enables us to compute public child care coverage rates on the county level and merge these data to our historical dialect data. In East Germany, as relict of the socialist past, we observe universal public child care coverage without any meaningful variation throughout all counties in the 1990s. Indeed, the socialist regime of the former GDR established an extensive public child care system with universal access to public child care already for very young children. By and large, this extensive public child care system survived reunification and is still present in today's East Germany. However, in West Germany, we still see large variation in public child care coverage for three to six year olds in 1994 (see Figure 1).

In order to increase public child care coverage in West Germany, in 1996, the German government introduced a legal claim to a half-day place in kindergarten for virtually all children aged three to six. During the first years after the introduction of the legal claim, cutoff rules had to be applied because child care slots were still scarce (see Bauernschuster and Schlotter, 2013). By 2002, the expansion of public child care for three to six year olds finally slowed down and reached a level where enough child care slots were available to meet the demand. Note that in the 1990s, child care facilities for three to six year old children were officially called "kindergartens" and Froebel's pedagogical ideas formed an integral part of institutionalized child care in Germany. 
Figure 1: Dialect similarity to Saalfeld-Rudolstadt and historical and contemporaneous child care

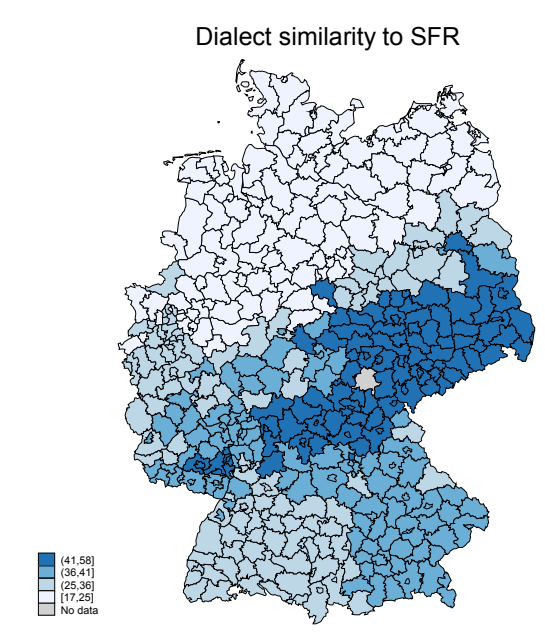

Child care coverage (3-6) 1994

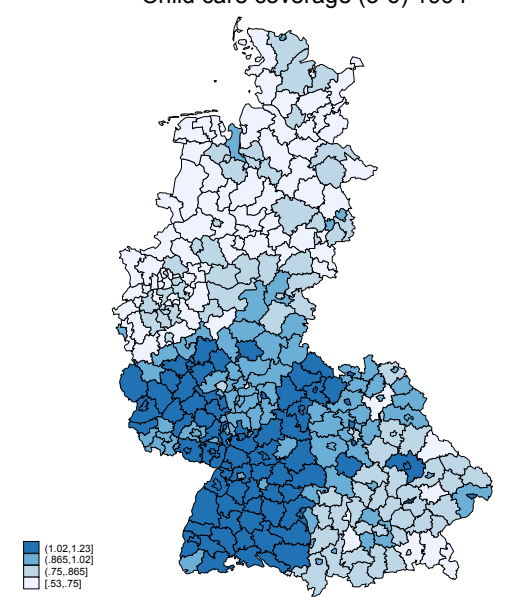

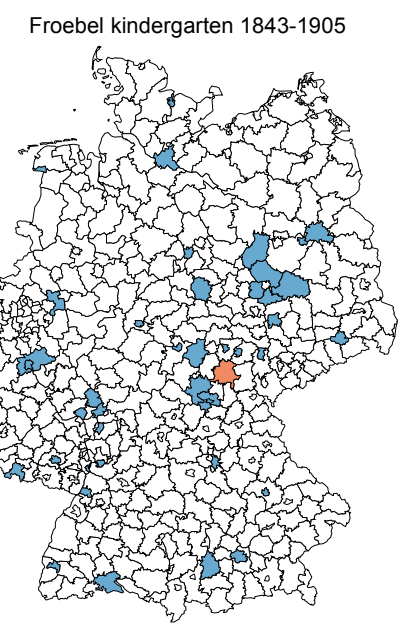

Child care coverage (u3) 2009

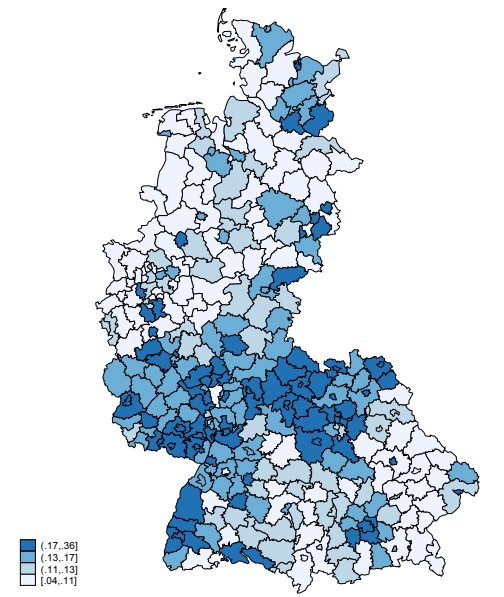


Although we see full provision of public child care for three to six year old children by 2002, public child care for children younger than three was virtually non-existing in West Germany. It was not before 2005 that the German government started meaningful policy initiatives to also increase public child care coverage for under three year olds in West Germany. These initiatives triggered off an expansion of public child care coverage in the late 2000 s that has not come to an end until the present day. The large expansion is indispensable since a legal claim to a place in public child care for all children aged one and above was introduced in August 2013. We use data from the Statistical Offices of the German Laender on the number of public child care slots for under three year olds for each German county in the year 2009. Again, we can compute public child care coverage rates since the Statistical Offices of the German Laender also provide us with data on the number of children under the age of three living in each county. Figure 1 provides graphic evidence for the spatial distribution of public child care coverage for under three year olds across West German counties in 2009.

In Figure 2, we plot public child care coverage for three to six year olds in 1994 and under three year olds in 2009 against dialect similarity to Saalfeld-Rudolstadt. The emerging pattern provides some first evidence of a positive raw correlation between dialect similarity to Saalfeld-Rudolstadt and public child care coverage in the 1990s and 2000s in West Germany. In particular for public child care coverage for three to six year olds in 1994, a positive raw correlation which is not driven by single outliers is easy to see. For public child care coverage of under three year olds in 2009 , the pattern is not as pronounced but a slight positive association can also be detected upon first inspection.

Figure 2: Dialect similarity to Saalfeld-Rudolstadt and public child care coverage: scatter plots
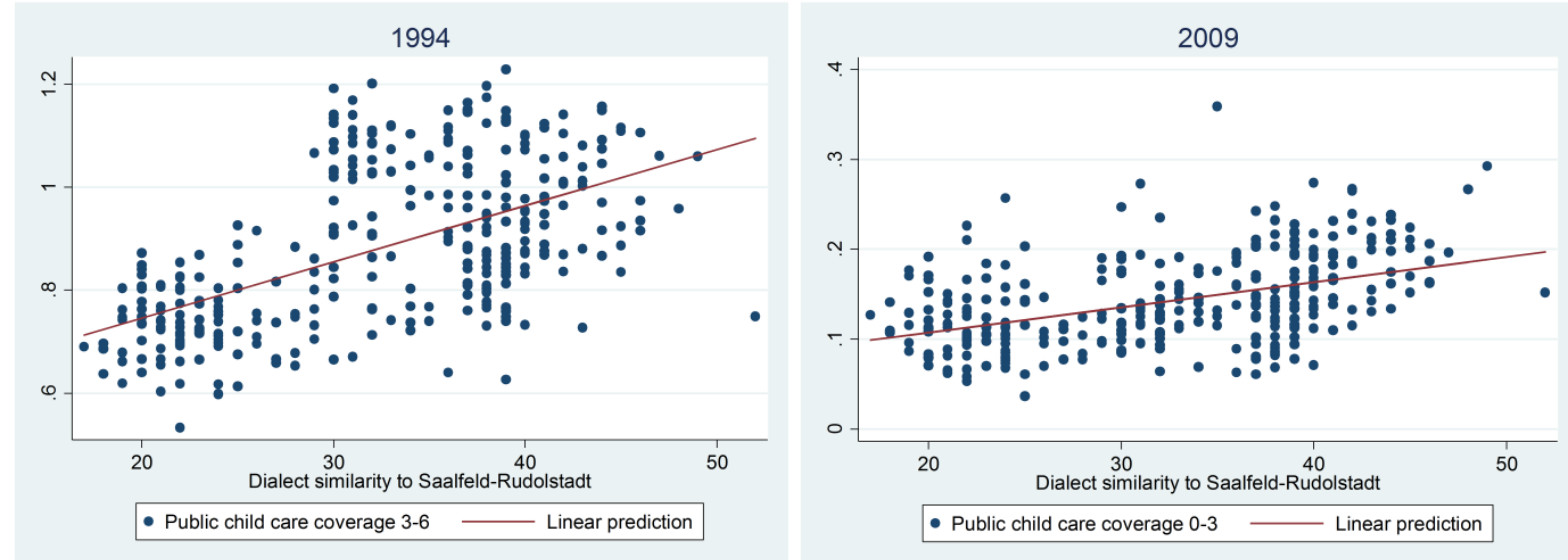


\subsection{Data on further regional characteristics}

Historical regional characteristics complement our data set of early Froebel kindergartens. In particular, since the $19^{\text {th }}$ century was the time of the industrial revolution in Germany, we might wish to control for a county's industry structure in our multivariate regressions covering this time period. The German workplace and population census for the year 1925 provides us with data on regional industry employment for 24 industry branches and for 97 functional regions (Raumordnungsregion). We can uniquely assign each of the 439 German districts to one of those functional regions. We then calculate an index measuring the dissimilarity between a region's industry structure and Saalfeld-Rudolstadt's industry structure as follows: i) for each industry and functional region we calculate the share of that industry in this region's total employment, ii) for all industries and functional regions we calculate the absolute value of the difference in the sectoral employment shares of the respective functional region to the sectoral employment shares of Saalfeld-Rudolstadt, iii) we sum those absolute differences across the 24 industries for all functional regions, iv) we then assign the resulting value of industrial dissimilarity to all counties within a functional region. Moreover, to capture differences in religious attitudes and social norms, we draw on a map from Meyers Konservations Lexikon, $4^{\text {th }}$ edition, 1885-1892, depicting historical shares of Catholics in 1890. Our variable measures decile differences in historical shares of Catholics between each county and Saalfeld-Rudolstadt. Furthermore, we use information on the land slope, i.e., the difference between the maximum and minimum elevations in meters. The slope can influence agricultural productivity and thus be a proxy for a region's historical prosperity. To be consistent with the definition of the previous variables, we use the differences in land slope between each county and Saalfeld-Rudolstadt. Finally, in order to account for unobserved regional heterogeneity in our regressions we have gathered information on the state to which each county belonged to during the German Confederation ("Deutscher Bund") from 1815 until 1866. Based on historical maps, we have assigned all counties to one of 35 states.

For the years 1994 and 2009, we use administrative data on county level characteristics from the Statistical Offices of the German Laender. These measures include the counties' GDP per capita, population density, an indicator whether the county is an urban municipality 
("kreisfreie Stadt") or not, and the share of Catholics and Protestants ${ }^{3}$. To further control for political and social attitudes, we use the vote share of the conservatives, the social democrats, the green party and the liberal party in the last general elections. The share of highly qualified individuals in total employment, the share of females in total employment, and the share of individuals employed in the manufacturing sector are calculated from the German Social Security Statistics and should capture important regional labor market characteristics. Moreover, to account for differences in local public finance, we use municipalities' gross income and debts aggregated at the county level. ${ }^{4}$ Finally, we have collected data on the number of German inhabitants in a county that fled from the Soviet occupation zone to measure migration from East to West before the Berlin Wall was erected. This unique data stems from the population census 1961. A descriptive overview of all variables included in our three regional data sets is provided in Table 2.

\footnotetext{
${ }^{3}$ The share of Catholics and Protestants stems from the population census in 1987; the information is missing for the county of Hannover. Unfortunately, no official county level data on religious affiliation is available after that year.

${ }^{4}$ The West German city states of Hamburg and Bremen (consisting of Bremen and Bremerhaven) have missing values in municipalities' gross income and debts. In 2009, there is a substantial number of missing values for municipalities' gross income in the official data. In particular, we lose all observations from NorthrhineWestphalia.
} 
Table 2: Regional level data: Descriptives

\begin{tabular}{|c|c|c|c|}
\hline & $\mathrm{N}$ & Mean & Std.dev. \\
\hline \multicolumn{4}{|l|}{ 1839-1905 } \\
\hline Froebel kindergarten & 439 & 0.093 & 0.291 \\
\hline Dialect similarity to SLF & 439 & 34.815 & 10.265 \\
\hline Geographic distance to SLF (in meter) & 439 & 239,131 & 99,606 \\
\hline Historical industry dissimilarity & 439 & 0.142 & 0.108 \\
\hline Difference in historical catholic share & 439 & 2.731 & 2.846 \\
\hline Difference in land slope & 439 & -217.636 & 294.828 \\
\hline
\end{tabular}

1994

West sample

\begin{tabular}{|c|c|c|c|}
\hline Public child care coverage (3-6) & 326 & 0882 & 0.156 \\
\hline Dialect similarity to SLF & 326 & 32.475 & 8.022 \\
\hline Geographic distance to SLF (in meter) & 326 & 259,498 & 86,694 \\
\hline Population density (in 1,000) & 326 & 0.567 & 0.700 \\
\hline GDP per capita (in $1,000 €)$ & 326 & 22.863 & 8.295 \\
\hline Catholic share in 1987 & 325 & 0.475 & 0.274 \\
\hline Protestant share in 1987 & 325 & 0.411 & 0.239 \\
\hline Conservatives vote share & 326 & 0.445 & 0.081 \\
\hline Social democratic party vote share & 326 & 0.362 & 0.085 \\
\hline Green party vote share & 326 & 0.070 & 0.025 \\
\hline Liberal party vote share & 326 & 0.073 & 0.021 \\
\hline Highly qualified employment share & 326 & 0.056 & 0.030 \\
\hline Female employment share & 326 & 0.332 & 0.037 \\
\hline Manufacturing employment share & 326 & 0.405 & 0.115 \\
\hline Municipalities' gross income & 323 & 339,977 & 384,107 \\
\hline Municipalities' debts & 323 & 226,179 & 315,478 \\
\hline Urban municipality & 326 & 0.276 & 0.448 \\
\hline Fugitives from Soviet occupation zone in 1,000 in 1961 & 326 & 8.384 & 12.163 \\
\hline le & & & \\
\hline Public child care coverage $(0-3)$ & 325 & 0.142 & 0.050 \\
\hline Dialect similarity to SLF & 325 & 32.489 & 8.031 \\
\hline Geographic distance to SLF (in meter) & 325 & 259,167 & 86,621 \\
\hline Population density (in 1,000) & 325 & 0.565 & 0.693 \\
\hline GDP per capita (in $1,000 €)$ & 325 & 29.208 & 10.688 \\
\hline Catholic share in 1987 & 324 & 0.474 & 0.274 \\
\hline Protestant share in 1987 & 324 & 0.412 & 0.239 \\
\hline Conservatives vote share & 325 & 0.365 & 0.071 \\
\hline Social democratic party vote share & 325 & 0.231 & 0.066 \\
\hline Green party vote share & 325 & 0.106 & 0.033 \\
\hline Liberal party vote share & 325 & 0.152 & 0.028 \\
\hline Highly qualified employment share & 325 & 0.100 & 0.047 \\
\hline Female employment share & 325 & 0.332 & 0.029 \\
\hline Manufacturing employment share & 325 & 0.305 & 0.096 \\
\hline Municipalities' gross income & 263 & 340,983 & 467,253 \\
\hline Municipalities' debts & 322 & 201,122 & 265,529 \\
\hline Urban municipality & 325 & 0.274 & 0.447 \\
\hline Fugitives from Soviet occupation zone in 1,000 in 1961 & 325 & 8.411 & 12.212 \\
\hline
\end{tabular}

Note: The table shows mean values (Mean) and standard deviations (Std.dev.). Observational units are counties; Germany consists of 439 counties, of which 326 counties are in West Germany. In 2009, the West German former counties "Stadt Aachen” and "Kreis Aachen” are merged to the new county "Staedteregion Aachen”. 


\section{Evidence for the role of culture for the spatial diffusion of Froebel's ideas}

In order to assess the role of culture for the spatial diffusion of Froebel's child care idea, we run simple multivariate regressions of the form

$$
y_{i}=\alpha+\beta s_{i S L F}+\gamma d_{i S L F}+X_{i} \delta+\varepsilon_{i}
$$

where $S_{i S L F}$ is the dialect similarity of county $i$ to Saalfeld-Rudolstadt, $d_{i S L F}$ is the geographic distance of county $i$ to Saalfeld-Rudolstadt, and $X_{i}$ is a vector of characteristics of county $i$. $y_{i}$ is a dichotomous variable indicating the presence of an early Froebel kindergarten in county $i$ in our historical regressions for the period 1839 to 1905, or the public child care coverage rate of county $i$ in the regressions for the years 1994 and 2009. Note that $\beta$ has a causal interpretation if $s_{i S L F}$ is uncorrelated with the error term $\varepsilon_{i}$, conditional on $X_{i}$. This is the conditional independence or selection on observables assumption. If Saalfeld-Rudolstadt became the cradle of Froebel kindergartens due to personal reasons of Friedrich Froebel and not because it was, for any other reasons, a particularly suitable location, a county's cultural proximity to Saalfeld-Rudolstadt should be exogenous to the innovative pedagogical ideas of Friedrich Froebel. Apart from historical accounts, we will later also provide empirical evidence for the validity of this assumption.

\subsection{Historical evidence}

We start our empirical investigation of the effects of cultural proximity to Friedrich Froebel's place of activity, Saalfeld-Rudolstadt, on the diffusion of his ideas using historical county level data. To this end, we first regress the dichotomous variable indicating the presence of an early Froebel kindergarten in the $19^{\text {th }}$ century on our index variable measuring the county's dialect similarity to Saalfeld-Rudolstadt in the $19^{\text {th }}$ century. As can be seen from column 1 of Table 4, this bivariate regression yields a highly significant and positive coefficient. A one standard deviation increase in dialect similarity to Saalfeld-Rudolstadt increases the likelihood that a county has adopted Froebel's ideas and established a Froebel kindergarten by 4.2 percentage points. This effect remains robust even if we control for geographic distance of a county to Saalfeld-Rudolstadt; interestingly, there is no additional significant association of geographic distance to Saalfeld-Rudolstadt on a county's likelihood of having established a Froebel kindergarten in the $19^{\text {th }}$ century (see column 2 of Table 4). 
Since the $19^{\text {th }}$ century was the time of the industrial revolution in Germany and industry structure might affect demand for child care, we also control for differences and similarities between counties' industry structure. The results of the respective regression show that the introduction of this control variable leaves our main result unaffected (column 3 of Table 4). In column 4 of Table 4, we additionally include the historical share of Catholics in a county to proxy for a society's attitudes and values. Again, our results do not change. Furthermore, we control for the slope of a region since it might influence agricultural productivity and via this channel regional prosperity in former times (Falck et al., 2012). As can be seen from column 5 of Table 4, we still find a positive and significant effect of cultural proximity to SaalfeldRudolstadt on the prevalence of an early Froebel kindergarten. Nor does including a dummy variable indicating whether a county was part of the same historical German state as Saalfeld-Rudolstadt change this picture (column 6 of Table 4).

We might wonder whether dialect similarity to Saalfeld-Rudolstadt merely captures nonlinearities of geographic distance to Saalfeld-Rudolstadt. To investigate whether this is the case, we additionally include the square (and cubic) terms of geographic distance to Saalfeld-Rudolstadt. Our results are virtually unaffected by these alternative specifications (columns 7 and 8 of Table 4). Finally, instead of the variable indicating whether a county is situated in the same German state as Saalfeld-Rudolstadt, we control for an extensive set of 35 German state dummies to capture institutional differences at that time. The regression results in column 9 of Table 4 show that - even allowing for unobserved heterogeneity between German states - we still observe a statistically significant and positive effect of dialect similarity to Froebel's place of action on the prevalence of a Froebel kindergarten. Note that this last specification is very restrictive since we only exploit within German state variation in our dialect similarity index to estimate the effect of dialect similarity to SaalfeldRudolstadt on the prevalence of a Froebel kindergarten.

\section{Robustness checks}

Instead of using dialect similarity to Saalfeld-Rudolstadt as the key explanatory variable while controlling for geographic distance, we might also use the residuals of regression equation (1) as the variable of interest. These residuals can be interpreted as variation in dialect similarity between a specific county and Saalfeld-Rudolstadt that is stripped off any 
(linear and quadratic) effects of geographic distance. We run regressions using this alternative explanatory variable and find our results confirmed (see Table A.1).

We also build a dummy variable which takes on the value of unity for the cities Leipzig, Kassel, Gotha, Hamburg, Berlin, Munich, Tuebingen, Darmstadt, and Dresden. These cities are well-known as the cradles of the early women's movement. Including this dummy variable and its interaction with the dialect similarity to Saalfeld-Rudolstadt in our regression gives us another interesting result. We find that the women's movement indicator has a highly significant and positive association with the prevalence of early Froebel kindergartens. At the same time, the interaction with the variable depicting dialect similarity to SaalfeldRudolstadt also comes out positive and significant (see Table A.2). This result confirms our presumption that the women's movement provided fertile ground for Froebel's kindergarten idea.

The results are virtually identical if we only use the Froebel kindergartens reported in the official statistics from the "Kindergarten" journals from 1895 and 1905 and dismiss the information provided in Friedrich Froebel's reports and personal letters from 1843 and 1847. Detailed results are available from the authors upon request.

Since we have identified early Froebel kindergartens in only 9.3 percent of all counties in our data set, we might wonder whether the large number of zeros in our outcome variable jeopardizes the empirical results. To test the robustness of our results, we run regressions on subsamples where those counties are excluded that are in the lowest 10,25 , and 50 percentile of the distribution of geographic distance to Saalfeld-Rudolstadt. Our results are qualitatively robust across all subsamples with the point estimates even increasing in the smaller samples. Detailed results are available from the authors upon request. 
Table 4: Cultural proximity to Saalfeld-Rudolstadt and Froebel kindergartens 1843-1905

\begin{tabular}{|c|c|c|c|c|c|c|c|c|c|}
\hline & & & & FROEBE & KINDERGA & TEN 1843- & & & \\
\hline & $(1)$ & $(2)$ & (3) & $(4)$ & $(5)$ & $(6)$ & $(7)$ & $(8)$ & (9) \\
\hline Dialect similarity to SLF & $0.004^{* * *}$ & $0.003^{*}$ & $0.004^{* *}$ & $0.005^{* *}$ & $0.005^{\star *}$ & $0.005^{\star *}$ & $0.005^{\star *}$ & $0.005^{* *}$ & $0.005^{*}$ \\
\hline & $(0.001)$ & $(0.002)$ & $(0.002)$ & $(0.002)$ & $(0.002)$ & $(0.002)$ & $(0.002)$ & $(0.002)$ & $(0.003)$ \\
\hline Geographic distance to SLF & & -0.001 & -0.001 & -0.000 & -0.002 & -0.002 & -0.003 & -0.006 & $0.047^{* *}$ \\
\hline & & $(0.002)$ & $(0.002)$ & $(0.002)$ & $(0.002)$ & $(0.002)$ & $(0.008)$ & $(0.020)$ & $(0.021)$ \\
\hline Geographic distance to SLF ${ }^{2}$ & & & & & & & 0.000 & 0.000 & $-0.002^{* *}$ \\
\hline & & & & & & & $(0.000)$ & $(0.001)$ & $(0.001)$ \\
\hline Geographic distance to SLF ${ }^{3}$ & & & & & & & & -0.000 & $0.000^{*}$ \\
\hline & & & & & & & & $(0.000)$ & $(0.000)$ \\
\hline Historical industry similarity & & & 0.265 & 0.273 & 0.263 & 0.263 & 0.264 & 0.264 & 0.262 \\
\hline & & & $(0.215)$ & $(0.212)$ & $(0.204)$ & $(0.205)$ & $(0.205)$ & $(0.205)$ & $(0.215)$ \\
\hline Difference in historical catholic share & & & & $-0.009^{* *}$ & -0.004 & -0.003 & -0.003 & -0.003 & -0.002 \\
\hline & & & & $(0.004)$ & $(0.004)$ & $(0.004)$ & $(0.005)$ & $(0.005)$ & $(0.005)$ \\
\hline Difference in land slope (/1000) & & & & & $-0.146^{* * *}$ & $-0.147^{* * *}$ & $-0.146^{* * *}$ & $-0.146^{* * *}$ & $-0.179^{* * *}$ \\
\hline & & & & & $(0.045)$ & $(0.045)$ & $(0.045)$ & $(0.045)$ & $(0.051)$ \\
\hline Different German state & & & & & & $-0.786^{\star * *}$ & $-0.772^{* * *}$ & $-0.758^{* * *}$ & \\
\hline & & & & & & $(0.053)$ & $(0.083)$ & $(0.144)$ & \\
\hline German state dummies & No & No & No & No & No & No & No & No & Yes \\
\hline $\mathrm{N}$ & 439 & 439 & 439 & 439 & 439 & 439 & 439 & 439 & 439 \\
\hline $\mathrm{R}^{2}$ & 0.021 & 0.022 & 0.030 & 0.037 & 0.055 & 0.071 & 0.071 & 0.071 & 0.246 \\
\hline
\end{tabular}




\section{Exogeneity of Saalfeld-Rudolstadt}

We have argued that the reason why Friedrich Froebel founded the first kindergarten in Saalfeld-Rudolstadt simply was that this was the county where he grew up. Therefore, Saalfeld-Rudolstadt happened to be the cradle of Froebel kindergartens by mere chance, and not because it was, for any other reasons, a particularly suitable location. As a consequence, a county's cultural proximity to Saalfeld-Rudolstadt should also be exogenous to the innovative pedagogical ideas of Friedrich Froebel. We can investigate the validity of this assumption by looking into associations between dialect similarity to Saalfeld-Rudolstadt and other historical data. In particular, we draw on data from the Statistical Yearbook of German Cities 1904 (Statistisches Jahrbuch deutscher Städte 1904), which contains data on German cities with more than 100,000 inhabitants.

In a first step, we analyse whether the prevalence of a major city is partially correlated with dialect similarity or geographic distance to Saalfeld-Rudolstadt. As can be seen from column 1 of Table 5, this is clearly not the case. Despite the fact that there are not more major cities in regions which are both, culturally or geographically closer to Saalfeld-Rudolstadt, major cities which are close to Saalfeld-Rudolstadt might be different from major cities which are (culturally or geographically) more distant to Saalfeld-Rudolstadt. To investigate whether this is true, we take the subsample of major cities and regress some selected characteristics of these cities on both the dialect similarity as well as the geographic distance to SaalfeldRudolstadt. Columns 2 through 4 of Table 5 indicate that neither cultural nor geographic distance to Saalfeld-Rudolstadt is correlated with the founding year of the $1^{\text {st }}$ library in a city, the growth of a city's population from 1871 to 1900, and population density in 1900 . Thus, these estimates provide some quantitative evidence that the cultural proximity to SaalfeldRudolstadt was indeed exogenous to the innovative pedagogical ideas of Friedrich Froebel and that, thus, the correlation between cultural proximity and the prevalence of early kindergartens might indeed depict the effect of cultural proximity on the diffusion of Froebel's ideas.

The Statistical Yearbook of German Cities 1904 also provides us with data on the total number of "Bewahranstalten" (child storage facilities), infant schools and kindergartens in major German cities in 1901/02. Unfortunately, the data do not distinguish between these different kinds of facilities ("Anstalten"). However, we know that, at that time, most of the 
649 facilities listed in the Statistical Yearbook of German Cities were not kindergartens in Froebel's sense but rather child storage facilities and infant schools. Therefore, cultural proximity to Saalfeld-Rudolstadt should not be correlated with the total number of "Anstalten" in a city in 1901/02. Indeed, as column 5 of Table 5 shows, the correlation is not statistically different from zero, which further supports our view that the cultural proximity to Saalfeld-Rudolstadt was indeed exogenous to the Froebel's ideas. ${ }^{5}$

Table 5: Exogeneity of cultural proximity to Saalfeld-Rudolstadt

\begin{tabular}{lccccc}
\hline & Major city & $\begin{array}{c}\text { Founding year } \\
1^{\text {st }} \text { library }\end{array}$ & $\begin{array}{c}\text { City growth } \\
1871-1900\end{array}$ & $\begin{array}{c}\text { Population } \\
\text { density } 1900\end{array}$ & $\begin{array}{c}\text { "Anstalten" } \\
(5)\end{array}$ \\
\hline \hline Dialect similarity to SLF & $(1)$ & $(2)$ & $(3)$ & $(4)$ & 0.090 \\
& -0.001 & 7.444 & 0.004 & 1.996 & $(0.380)$ \\
Geographic distance to SLF & $(0.001)$ & $(5.300)$ & $(0.011)$ & $(0.755)$ & 0.249 \\
& -0.000 & 0.001 & 0.001 & 2.048 & $(0.391)$ \\
\hline $\mathrm{N}$ & $(0.000)$ & $(0.001)$ & $(0.017)$ & $(1.766)$ & 36 \\
$\mathrm{R}^{2}$ & 439 & 24 & 24 & 24 & 0.013 \\
\hline
\end{tabular}

Note: The table shows results of OLS regressions; robust standard errors in parentheses. ${ }^{* * *} 1 \%$ level of significance, ** $5 \%$ level of significance, * $10 \%$ level of significance.

\subsection{Evidence from the 1990s and 2000s}

Moving forward in time, we now turn to public child care coverage rates for three to six year olds in German counties in 1994. We might expect a correlation between cultural proximity to Froebel's birthplace and public child care coverage at that time if familiarity to Froebel's ideas makes child care usage (already for rather young children) more acceptable, or even desirable, if people hold the view that external child care can be a beneficial complement to maternal care and thus foster a child's development. An alternative explanation could be that child care institutions are long-living, i.e., locations that built kindergartens in the tradition of Froebel in the $19^{\text {th }}$ century still have these kindergartens at the end of the $20^{\text {th }}$ and the beginning of the $21^{\text {st }}$ century.

It is well-known that the socialist regime of the former German Democratic Republic (GDR) supported female employment and established full public child care coverage already for very young children whereas the West German government rather promoted the traditional male breadwinner model. As a consequence, when East and West Germany reunified in

\footnotetext{
${ }^{5}$ Further unreported regressions reveal that the number of "Anstalten" in a city in 1901/02 is not positively correlated with public child care coverage in 1994. This is in line with our assumption that "Anstalten" are institutions qualitatively different from Froebel kindergartens or today's public child care centers.
} 
1990, public child care coverage was far lower in West Germany than in East Germany. To ensure that our results are not driven by a mere East-West comparison in which the socialist past acts as a confounding factor, we focus on West German counties in the following analyses. Remember that in the 1990s, child care facilities for three to six year old children were officially called "kindergartens" and Froebel's pedagogical ideas were an integral part of institutional child care in Germany.

A bivariate regression of child care coverage rates on the dialect similarity measure yields a highly significant and positive effect of dialect similarity to Saalfeld-Rudolstadt on public child care coverage for children at kindergarten age. The coefficient from column 1 of Table 6 indicates that a one standard deviation increase in dialect similarity to Frobel's place of activity is associated with a 9 percentage points higher public child care coverage rate in that county in 1994. Additionally controlling for the geographic distance of a county to SaalfeldRudolstadt in column 2 of Table 6 does hardly affect this result. The coefficient on dialect similarity to Saalfeld-Rudolstadt remains highly significant and positive; indeed, the size of the coefficient has even slightly increased.

In column 3 of Table 6, we include further covariates, namely a county's GDP per capita, population density as well as a dichotomous variable indicating urban municipalities. However, the association between cultural proximity to Saalfeld-Rudolstadt and child care coverage rates remains remarkably stable. The same holds true if we add the share of Catholics and Protestants as covariates to the regression (column 4 of Table 6). To control for political attitudes, we include the county-specific vote shares of the conservatives, the social democrats, the green party, and the liberal party in the last general elections. Again, the association between cultural proximity to Saalfeld-Rudolstadt and public child care coverage stays highly significant and positive (column 5 of Table 6). To capture local labor market differences, we further include the employment share of highly qualified individuals and the employment share of females as well as the share of individuals working in the manufacturing sector. The share of females can also be interpreted as a proxy for social progressiveness in general and in particular for the role of women in the local society. These additional controls do not affect our results as can be seen from column 6 of Table 6 . Since local public finance might affect public child care rates, we additionally include municipalities' gross income and debts in column 7 of Table 6, which again leaves our results unaffected. Note that all these county characteristics are not fixed at the time we measure 
cultural proximity to Saalfeld-Rudolstadt. Therefore, one might argue that these variables should not be included as controls in order to avoid so called bad control problems which boil down to selection bias (Angrist and Pischke, 2009). Yet, in our specific case, it is also reassuring to see that the inclusion of all these control variables does not affect the coefficient of the dialect similarity variable at all. 
Table 6: Cultural proximity to Saalfeld-Rudolstadt and public child care coverage in 1994

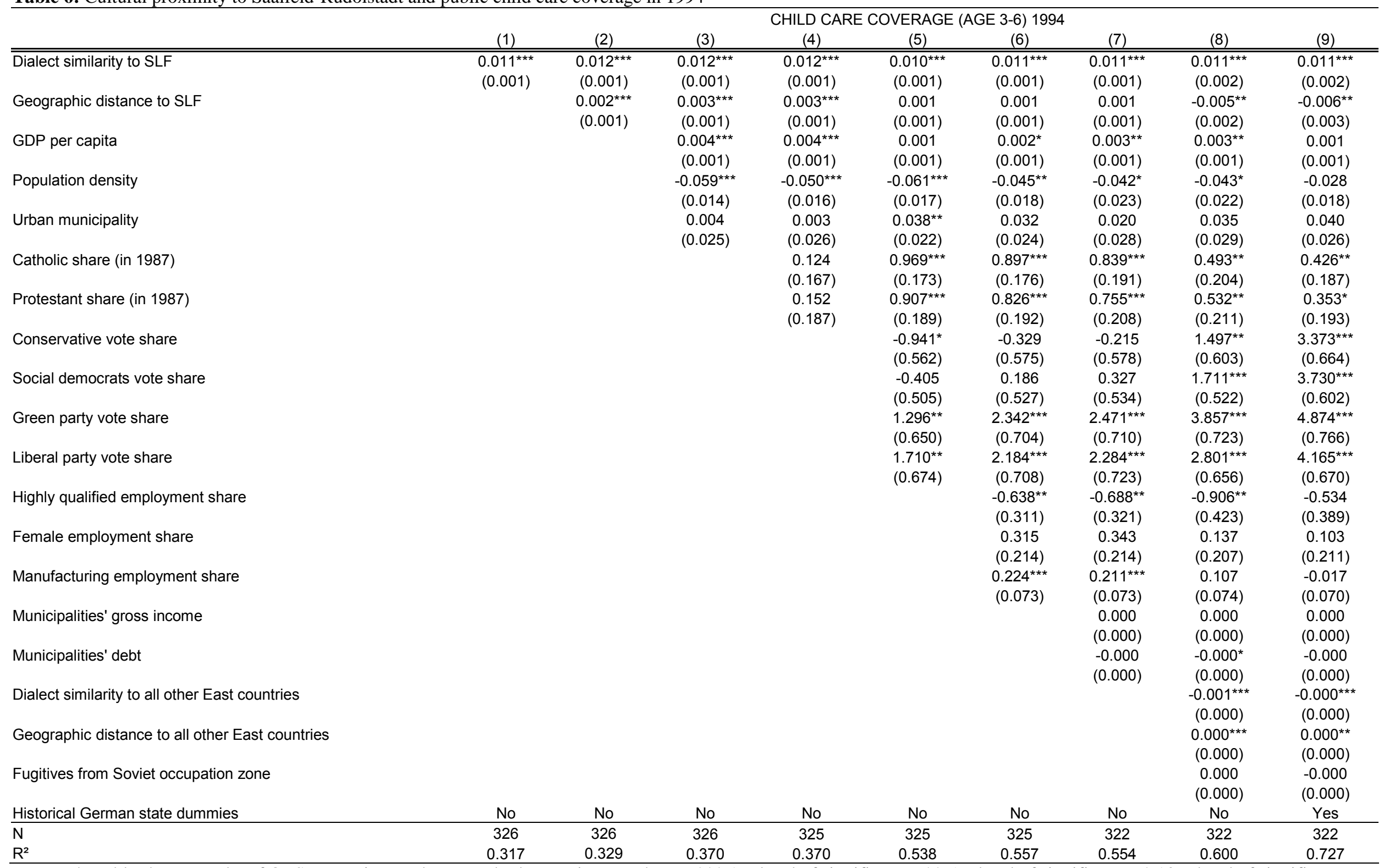

Note: The table shows results of OLS regressions; robust standard errors in parentheses. $* * * 1 \%$ level of significance, $* * 5 \%$ level of significance, * $10 \%$ level of significance. 
A remaining concern is that migration from East Germany to specific locales in West Germany may correlate with the effect of dialect similarity with Saalfeld-Rudolstadt and affect public child care coverage. Therefore, we should test whether our results could be explained by this special migration pattern. For this purpose, we compute population weighted dialect similarity and population weighted geographic distance measures between a West German county and all East German counties but Saalfeld-Rudolstadt according to the following formulas ${ }^{6}$ :

$$
\begin{aligned}
& S_{i}=\sum_{j} s_{i j} * p_{j} \\
& D_{i}=\sum_{j} d_{i j} * p_{j}
\end{aligned}
$$

$s_{i j}$ is the dialect similarity of a West German county $i$ to an East German county $j, d_{i j}$ is the geographic distance of a West German county $i$ to an East German county $j, p_{j}$ is the population of an East German county $j$, where $j$ includes all East German counties but Saalfeld-Rudolstadt. In addition to these two measures, we also use unique data on German inhabitants in a county that fled from the Soviet occupation zone (measured in 1961) to capture migration from East to West Germany before the Berlin Wall was erected.

We find that our results are robust to including these measures as further control variables in our regression (column 8 of Table 6 ). The fact that the variable measuring dialect similarity to all other East German counties even has a negative sign provides further evidence that it is not the cultural proximity to East Germany as such that drives our results but indeed the specific cultural proximity to the Saalfeld-Rudolstadt area. The results are very similar if we include the three (potential) migration measures separately. Finally, we even include the set of historical German state dummies to control for unobserved heterogeneity across regions and still receive very similar results (column 9 of Table 6). ${ }^{7}$

In further unreported regressions, we also include the square and cubic terms of geographic distance to Saalfeld-Rudolstadt in order to test whether our dialect similarity measure simply picks up any nonlinearities of geographic distance. It turns out that our dialect similarity measure does not just capture nonlinearities of geographic distance; indeed, the coefficient on dialect similarity is virtually unaffected by this specification.

\footnotetext{
${ }^{6}$ We thank an anonymous referee for this suggestion.

${ }^{7}$ Additionally controlling for the geographic distance to Zurich, Pestalozzi's place of activity, leaves our cultural proximity effect unchanged while the geographic distance coefficient is significantly negative.
} 
In a next step, we look at child care coverage rates in 2009. In this year, we cannot draw on any meaningful variation in public child care for three to six year olds across West German counties as a result of the introduction of the legal claim to a half-day place in kindergarten for all children aged three to six in 1996. However, as explained above we still observe substantial variation in public child care coverage for under three year olds. Again, we focus on the West German sample for the reasons discussed above and run regressions that are analogous to those for kindergarten coverage rates in 1994. Column 1 of Table 7 shows the results of a bivariate regression of public child care coverage for children younger than three on dialect similarity to Froebel's place of activity. Again, we find a highly significant and positive association between our cultural proximity measure and public child care coverage. A one standard deviation increase in cultural proximity increases a county's child care coverage by 2.2 percentage points. Conditional on cultural proximity, geographic distance to Saalfeld-Rudolstadt is not associated with public child care coverage for children under three. At the same time, the inclusion of the geographic distance measures leaves the effect of cultural proximity on public child care coverage unaffected (column 2 of Table 7).

In column 3 of Table 7, we show that the finding is robust to the inclusion of a county's GDP per capita, population density, as well as a dichotomous variable indicating urban municipalities. In the remaining columns, we additionally control for the share of Catholics and the share of Protestants in a county, the vote shares of the conservatives, the social democrats, the green party, and the liberal party, the employment share of highly qualified persons, the employment share of females as well as the share of individuals working in the manufacturing sector, the municipalities' gross income and debts, the measures for dialect similarity and geographic distance to all other East German counties, the number of individuals that fled from the Soviet occupation zone as well as the extensive set of historical German state dummies. Cultural proximity to Saalfeld-Rudolstadt stays a remarkably stable predictor of public child care coverage for very young children in 2009 across all specifications.

We also run regressions where we take full-day public child care coverage for children aged three to six as the outcome variable. In 2009, there is substantial variation across West German counties with a mean coverage of 20 percent and a standard deviation of 12 percent. Again, we find a statistically highly significant, positive coefficient on cultural 
proximity to Froebel's place of activity, which is robust to the inclusion of all our county level control variables (see Table A.3).

We also test whether our results are confirmed using individual level data from waves 1985 until 2008 of the German Socio Economic Panel (SOEP version 25, 2009, doi:10.5684/soep.v25) (see Wagner et al. 2007). ${ }^{8}$ To this end, we regress public child care usage for a mother's youngest child on cultural similarity to Saalfeld-Rudolstadt while controlling for geographic distance to Saalfeld-Rudolstadt, year dummies and a set of potential individual level determinants of public child care usage such as a mother's age, years of schooling, partnership status, migration background. ${ }^{9}$ In line with the county-level results, we find that mothers living in counties which are culturally more similar to Froebel's place of activity, Saalfeld-Rudolstadt, are more likely to use public child care for their youngest child in West Germany. The respective correlation for East Germany, where the Socialist regime has levelled out any regional differences in public child care provision, is virtually zero. Descriptive statistics show that 95 percent of all six year olds attend kindergarten. Accordingly, the positive association in West Germany emerges because mothers living in counties culturally closer to Froebel's Saalfeld-Rudolstadt put their children into public child care at an earlier age rather than not putting them into public child care at all (Table A.5).

\footnotetext{
${ }^{8}$ Access to information on the county a household resides, which allows us to merge our dialect and geographic distance variables to the individual level data, was granted via controlled remote data processing. Descriptive statistics on our sample are presented in Tables A.4a and A.4b.

${ }^{9}$ Note that we do not control for a mother's employment status since the maternal labor supply decision is itself endogenous to public child care.
} 
Table 7: Cultural proximity to Saalfeld-Rudolstadt and public child care coverage in 2009

\begin{tabular}{|c|c|c|c|c|c|c|c|c|c|}
\hline \multirow{3}{*}{$\overline{\overline{\text { Dialect similarity to SLF }}}$} & \multicolumn{9}{|c|}{ CHILD CARE COVERAGE (AGE U3) 2009} \\
\hline & $(1)$ & $(2)$ & $(3)$ & $(4)$ & $(5)$ & $(6)$ & $(7)$ & $(8)$ & $(9)$ \\
\hline & $\begin{array}{c}0.003^{\star * \star} \\
(0.000)\end{array}$ & $\begin{array}{c}0.003^{\star \star \star} \\
(0.000)\end{array}$ & $\begin{array}{c}0.002^{\star \star \star} \\
(0.000)\end{array}$ & $\begin{array}{c}0.003^{\star \star \star} \\
(0.000)\end{array}$ & $\begin{array}{c}0.003^{\star \star \star} \\
(0.000)\end{array}$ & $\begin{array}{c}0.003^{\star \star *} \\
(0.000)\end{array}$ & $\begin{array}{c}0.003^{\star \star \star} \\
(0.001)\end{array}$ & $\begin{array}{c}0.003^{\star \star \star} \\
(0.001)\end{array}$ & $\begin{array}{c}0.002^{\star \star \star} \\
(0.001)\end{array}$ \\
\hline Geographic distance to SLF & & $\begin{array}{l}-0.000 \\
(0.000)\end{array}$ & $\begin{array}{l}-0.000 \\
(0.000)\end{array}$ & $\begin{array}{l}-0.000 \\
(0.000)\end{array}$ & $\begin{array}{c}-0.001^{*} \\
(0.000)\end{array}$ & $\begin{array}{l}-0.000 \\
(0.000)\end{array}$ & $\begin{array}{l}-0.000 \\
(0.000)\end{array}$ & $\begin{array}{l}0.000 \\
(0.001)\end{array}$ & $\begin{array}{c}-0.003^{* * *} \\
(0.001)\end{array}$ \\
\hline GDP per capita & & & $\begin{array}{l}0.001^{* *} \\
(0.000)\end{array}$ & $\begin{array}{l}0.001^{* *} \\
(0.000)\end{array}$ & $\begin{array}{c}0.000 \\
(0.000)\end{array}$ & $\begin{array}{l}-0.000 \\
(0.000)\end{array}$ & $\begin{array}{l}-0.001^{*} \\
(0.000)\end{array}$ & $\begin{array}{l}-0.001^{*} \\
(0.000)\end{array}$ & $\begin{array}{c}-0.001^{* *} \\
(0.000)\end{array}$ \\
\hline Population density & & & $\begin{array}{c}0.005 \\
(0.006)\end{array}$ & $\begin{array}{l}-0.002 \\
(0.007)\end{array}$ & $\begin{array}{c}-0.007 \\
(0.007)\end{array}$ & $\begin{array}{c}-0.013^{* *} \\
(0.006)\end{array}$ & $\begin{array}{l}-0.016 \\
(0.011)\end{array}$ & $\begin{array}{l}-0.014 \\
(0.011)\end{array}$ & $\begin{array}{c}-0.023^{* *} \\
(0.011)\end{array}$ \\
\hline Urban municipality & & & $\begin{array}{c}0.002 \\
(0.009)\end{array}$ & $\begin{array}{l}-0.002 \\
(0.010)\end{array}$ & $\begin{array}{c}0.000 \\
(0.008)\end{array}$ & $\begin{array}{c}0.004 \\
(0.008)\end{array}$ & $\begin{array}{c}0.012 \\
(0.011)\end{array}$ & $\begin{array}{c}0.009 \\
(0.011)\end{array}$ & $\begin{array}{c}0.012 \\
(0.012)\end{array}$ \\
\hline Catholic share (in 1987) & & & & $\begin{array}{c}-0.141^{* *} \\
(0.068)\end{array}$ & $\begin{array}{c}0.061 \\
(0.071)\end{array}$ & $\begin{array}{l}0.126^{*} \\
(0.072)\end{array}$ & $\begin{array}{l}0.135^{\star} \\
(0.074)\end{array}$ & $\begin{array}{l}0.157^{\star *} \\
(0.070)\end{array}$ & $\begin{array}{c}0.084 \\
(0.070)\end{array}$ \\
\hline Protestant share (in 1987) & & & & $\begin{array}{l}-0.102 \\
(0.076)\end{array}$ & $\begin{array}{c}0.066 \\
(0.078)\end{array}$ & $\begin{array}{l}0.155^{*} \\
(0.079)\end{array}$ & $\begin{array}{l}0.149^{\star} \\
(0.080)\end{array}$ & $\begin{array}{l}0.161^{* *} \\
(0.077)\end{array}$ & $\begin{array}{c}0.083 \\
(0.074)\end{array}$ \\
\hline Conservative vote share & & & & & $\begin{array}{c}-0.052 \\
(0.104)\end{array}$ & $\begin{array}{l}-0.118 \\
(0.099)\end{array}$ & $\begin{array}{l}-0.079 \\
(0.146)\end{array}$ & $\begin{array}{l}-0.170 \\
(0.153)\end{array}$ & $\begin{array}{l}-0.230 \\
(0.157)\end{array}$ \\
\hline Social democrats vote share & & & & & $\begin{array}{c}0.145 \\
(0.117)\end{array}$ & $\begin{array}{c}0.030 \\
(0.115)\end{array}$ & $\begin{array}{c}0.184 \\
(0.158)\end{array}$ & $\begin{array}{c}0.109 \\
(0.168)\end{array}$ & $\begin{array}{c}0.117 \\
(0.190)\end{array}$ \\
\hline Green party vote share & & & & & $\begin{array}{c}0.749^{* * *} \\
(0.143)\end{array}$ & $\begin{array}{c}0.214 \\
(0.163)\end{array}$ & $\begin{array}{c}0.186 \\
(0.221)\end{array}$ & $\begin{array}{c}0.158 \\
(0.231)\end{array}$ & $\begin{array}{c}0.217 \\
(0.252)\end{array}$ \\
\hline Liberal party vote share & & & & & $\begin{array}{c}0.138 \\
(0.111)\end{array}$ & $\begin{array}{l}-0.017 \\
(0.102)\end{array}$ & $\begin{array}{c}0.111 \\
(0.139)\end{array}$ & $\begin{array}{c}0.199 \\
(0.148)\end{array}$ & $\begin{array}{c}0.181 \\
(0.196)\end{array}$ \\
\hline Highly qualified employment share & & & & & & $\begin{array}{c}0.421^{* * *} \\
(0.097)\end{array}$ & $\begin{array}{c}0.396^{* * *} \\
(0.107)\end{array}$ & $\begin{array}{c}0.415^{\star * *} \\
(0.109)\end{array}$ & $\begin{array}{c}0.475^{\star * *} \\
(0.123)\end{array}$ \\
\hline Female employment share & & & & & & $\begin{array}{c}0.335^{* * *} \\
(0.124)\end{array}$ & $\begin{array}{l}0.321^{* *} \\
(0.141)\end{array}$ & $\begin{array}{l}0.345^{\star *} \\
(0.141)\end{array}$ & $\begin{array}{c}0.102 \\
(0.154)\end{array}$ \\
\hline Manufacturing employment share & & & & & & $\begin{array}{c}0.011 \\
(0.031)\end{array}$ & $\begin{array}{l}-0.015 \\
(0.037)\end{array}$ & $\begin{array}{c}0.014 \\
(0.041)\end{array}$ & $\begin{array}{c}0.006 \\
(0.055)\end{array}$ \\
\hline Municipalities' gross income & & & & & & & $\begin{array}{c}0.000^{\star \star *} \\
(0.000)\end{array}$ & $\begin{array}{c}0.000^{* \star *} \\
(0.000)\end{array}$ & $\begin{array}{c}0.000^{* * *} \\
(0.000)\end{array}$ \\
\hline Municipalities' debt & & & & & & & $\begin{array}{c}-0.000^{* * *} \\
(0.000)\end{array}$ & $\begin{array}{c}-0.000^{* * *} \\
(0.000)\end{array}$ & $\begin{array}{c}-0.000^{* * *} \\
(0.000)\end{array}$ \\
\hline Dialect similarity to all other East countries & & & & & & & & $\begin{array}{c}0.000 \\
(0.000)\end{array}$ & $\begin{array}{c}0.000 \\
(0.000)\end{array}$ \\
\hline Geographic distance to all other East countries & & & & & & & & $\begin{array}{l}-0.000 \\
(0.000)\end{array}$ & $\begin{array}{c}0.000 \\
(0.000)\end{array}$ \\
\hline Fugitives from Soviet occupation zone & & & & & & & & $\begin{array}{l}-0.000 \\
(0.000)\end{array}$ & $\begin{array}{l}-0.000 \\
(0.000)\end{array}$ \\
\hline Historical German state dummies & No & No & No & No & No & No & No & No & Yes \\
\hline $\mathrm{N}$ & 325 & 325 & 325 & 324 & 324 & 324 & 262 & 262 & 262 \\
\hline $\mathrm{R}^{2}$ & 0.203 & 0.204 & 0.251 & 0.321 & 0.464 & 0.526 & 0.529 & 0.539 & 0.645 \\
\hline
\end{tabular}

Note: The table shows results of OLS regressions; robust standard errors in parentheses. *** 1\% level of significance, ** 5\% level of significance, * $10 \%$ level of significance. 


\section{Conclusions}

Friedrich Froebel, a German pedagogue, established the first kindergarten worldwide in Thuringia in 1839. We study the spatial diffusion of the kindergarten movement in Germany in the $19^{\text {th }}$ and beginning of the $20^{\text {th }}$ century to analyse whether a common cultural background facilitates the spatial diffusion of ideas by making interaction between people more likely. Using historical data on local dialects to proxy cultural similarity, we provide evidence for the relevance of human interactions for the spatial diffusion of Friedrich Froebel's new kindergarten idea. The spatial diffusion of Froebel's pedagogical idea did not happen in concentric circles around his place of activity but followed a pattern which can be explained by the cultural proximity, measured by dialect similarity at the end of the 19th century, to Froebel's place of activity.

Second, we trace the child care movement from its beginnings in the $19^{\text {th }}$ century until the 2000s. We show that the spatial diffusion pattern of Frobel's kindergarten idea in the $19^{\text {th }}$ century has left long-lasting imprints in regions that early adopted Froebel's ideas. Concretely, end of $19^{\text {th }}$ century cultural proximity to Froebel's place of activity can explain the spatial pattern of child care use in the 1990s and 2000s. This contemporaneous correlation might be explained by either arguing that familiarity to Froebel's ideas is transmitted over generations and thus child care usage might be more acceptable or that child care institutions are long-living, i.e., locations that built kindergartens in the tradition of Froebel in the $19^{\text {th }}$ century still have these kindergartens at the end of the $20^{\text {th }}$ and the beginning of the $21^{\text {st }}$ century. Further research is needed to disentangle these two channels. 


\section{Literature}

Allen, Ann T. (1988), "Let Us Live with Our Children": Kindergarten Movements in Germany and the United States, 1840-1914, History of Education Quarterly, 28(1), 23-48.

Allen, Ann T. (2000), Children between Public and Private Worlds: The Kindergarten and Public Policy in Germany, 1840-Present, in: Wollons, Roberta and Rpberta Lyn Wollons (ed.), Kindergartens and Cultures: The Global Diffusion of an Idea, Yale University Press, $16-41$.

Angrist, Joshua D., and Joern-Steffen Pischke (2009), Mostly Harmless Econometrics, New York: Princeton University Press.

Artaria, Rosalie (1894), Die Führerinnen der Frauenbewegung in Deutschland, Die Gartenlaube 15, 256-259.

Bauernschuster, Stefan, Falck, Oliver, Heblich, Stephan, Suedekum, Jens, and Alfred Lameli (2014), Why Are Educated and Risk-loving Persons More Mobile Across Regions? Journal of Economic Behavior and Organization, 98, 56-69.

Bauernschuster, Stefan, and Martin Schlotter (2013), Public Child Care and Mothers' Labor Supply: Evidence from Two Quasi-Experiments, CESifo Working Paper No. 4191.

Becker, Sascha, and Ludger Woessmann (2009), Was Weber Wrong? A Human Capital Theory of Protestant Economic History, Quarterly Journal of Economics, 124(2), 531596.

Cantoni, Davide (2012), Adopting a New Religion: The Case of Protestantism in $16^{\text {th }}$ Century Germany, Economic Journal, 122(560), 502-531.

Comin, Diego, Dmitriev, Mikhail, and Esteban Rossi-Hansberg (2012), The Spatial Diffusion of Technology, NBER Working Paper No. 18534.

Dittmar, Jeremiah E. (2011), Information Technology and Economic Change: The Impact of the Printing Press, Quarterly Journal of Economics, 126(3), 1133-1172.

Falck, Oliver, Heblich, Stephan, Lameli, Alfred, and Jens Suedekum (2012), Dialects, Cultural Identity, and Economic Exchange, Journal of Urban Economics 72 (2-3), 225-239.

Guiso, Luigi, Paula Sapienza, and Luigi Zingales (2006), Does Culture Affect Economic Outcomes? Journal of Economic Perspectives, 20(2), 23-48. 
Guiso, Luigi, Sapienza, Paola, and Luigi Zingales (2009), Cultural Biases in Economic Exchange?, Quarterly Journal of Economics, 124(3), 1095-1131.

Heiland, Helmut (1997), Friedrich Froebels Beziehungen zu Quetz, in: Zoerbiger Bote, 12, 1214

Konrad, Franz-Michael (2004), Der Kindergarten - seine Geschichte von den Anfaengen bis in die Gegenwart, Freiburg im Breisgau: Lambertus.

Lameli, Alfred (2013): Strukturen im Sprachraum. Analysen zur arealtypologischen Komplexität der Dialekte in Deutschland. Berlin, Boston: De Gruyter.

Lange, Wichard (1862), Die Grundgedanken Friedrich Froebels, Erziehung der Gegenwart 2, 138-140, 147-148, 155-156, 161-163.

Michalopoulos, Stelios (2012), The Origins of Ethnolinguistic Diversity, American Economic Review, 102(4), 1508-1539.

Wagner, Gert, Frick, Joachim, and Jürgen Schupp (2007), The German Socio-Economic Panel Study (SOEP) - Scope, Evolution and Enhancements, Schmollers Jahrbuch 127(1), 139169.

Weiland, Daniela (1983), Geschichte der Frauenemanzipation in Deutschland und Oesterreich - Biographien, Programme, Organisationen, Duesseldorf: ECON.

Wollons, Roberta (2000), Introduction, in: Wollons, Roberta and Rpberta Lyn Wollons (ed.), Kindergartens and Cultures: The Global Diffusion of an Idea, Yale University Press, 115. 


\section{Appendix}

Table A.1: Cultural proximity to Saalfeld-Rudolstadt and Froebel kindergartens 1843-1905: alternative specification

\begin{tabular}{|c|c|c|c|c|c|c|}
\hline & \multicolumn{6}{|c|}{ FROEBEL KINDERGARTEN 1843-1905 } \\
\hline & \multicolumn{3}{|c|}{ linear prediction } & \multicolumn{3}{|c|}{ quadratic prediction } \\
\hline & $(1)$ & $(2)$ & (3) & $(4)$ & $(5)$ & $(6)$ \\
\hline \multirow[t]{2}{*}{ Cultural similarity to SLF } & $0.005^{* *}$ & $0.004^{* *}$ & 0.004 & $0.005^{* *}$ & $0.004^{* *}$ & $0.004^{*}$ \\
\hline & $(0.002)$ & $(0.002)$ & $(0.002)$ & $(0.002)$ & $(0.002)$ & $(0.002)$ \\
\hline \multirow[t]{2}{*}{ Historical industry similarity } & 0.130 & 0.141 & 0.276 & 0.126 & 0.139 & 0.276 \\
\hline & $(0.214)$ & $(0.213)$ & $(0.216)$ & $(0.214)$ & $(0.213)$ & $(0.214)$ \\
\hline \multirow[t]{2}{*}{ Difference in historical catholic share } & $-0.009^{*}$ & $-0.008^{*}$ & -0.005 & $-0.009^{*}$ & $-0.008^{*}$ & -0.005 \\
\hline & $(0.005)$ & $(0.005)$ & $(0.005)$ & $(0.005)$ & $(0.005)$ & $(0.005)$ \\
\hline \multirow[t]{2}{*}{ Difference in land slope (/1000) } & $-0.091^{* *}$ & $-0.097^{* *}$ & $-0.176^{* * *}$ & $-0.092^{* *}$ & $-0.098^{* *}$ & $-0.176^{* * *}$ \\
\hline & $(0.042)$ & $(0.041)$ & $(0.050)$ & $(0.042)$ & $(0.041)$ & $(0.050)$ \\
\hline \multirow[t]{2}{*}{ Different German state } & \multirow{2}{*}{\multicolumn{3}{|c|}{$\begin{array}{c}-0.867^{* * *} \\
(0.039)\end{array}$}} & \multirow{2}{*}{\multicolumn{3}{|c|}{$\begin{array}{c}-0.878^{* * *} \\
(0.037)\end{array}$}} \\
\hline & & & & & & \\
\hline German state dummies & No & No & Yes & No & No & Yes \\
\hline $\mathrm{N}$ & 439 & 439 & 439 & 439 & 439 & 439 \\
\hline $\mathrm{R}^{2}$ & 0.030 & 0.050 & 0.237 & 0.030 & 0.050 & 0.238 \\
\hline
\end{tabular}

Note: The table shows results of OLS regressions; robust standard errors in parentheses. The variable "cultural similarity to SLF" is the residual of a regression of dialect similarity on geographic distance (columns (1) through (3)), or the residual of a regression of dialect similarity on geographic distance and its square (columns (4) through (6)). $* * * 1 \%$ level of significance, ** $5 \%$ level of significance, * $10 \%$ level of significance. 
Table A.2: Cultural proximity to Saalfeld-Rudolstadt, women’s movement and Froebel kindergartens 1843-1905

FROEBEL KINDERGARTEN 1843-1905

coeff.

s.e.

Dialect similarity to SLF

0.004

0.002

Women's movement

$0.697^{* * *}$

0.118

Dialect similarity to SLF $x$ Women's movement

$0.030^{\star \star}$

0.014

Geographic distance to SLF

$0.042^{* *}$

0.020

Geographic distance to SLF ${ }^{2}$

$-0.002^{*}$

0.001

Geographic distance to SLF ${ }^{3}$

$0.000^{*}$

0.000

Historical industry similarity

0.073

0.134

Difference in historical catholic share

$-0.001$

0.005

Difference in land slope (/1000)

$-0.132$

0.043

German state dummies

\section{$\mathrm{N}$}

$\mathrm{R}^{2}$

439

439

0.360

Note: The table shows results of OLS regressions; robust standard errors in parentheses. Dialect distance to Saalfeld-Rudolstadt is normalized to be zero for the womens' movement cities on average. ${ }^{* * *} 1 \%$ level of significance, ** $5 \%$ level of significance, * $10 \%$ level of significance. 
Table A.3: Cultural proximity to Saalfeld-Rudolstadt and full-day public child care coverage in 2009

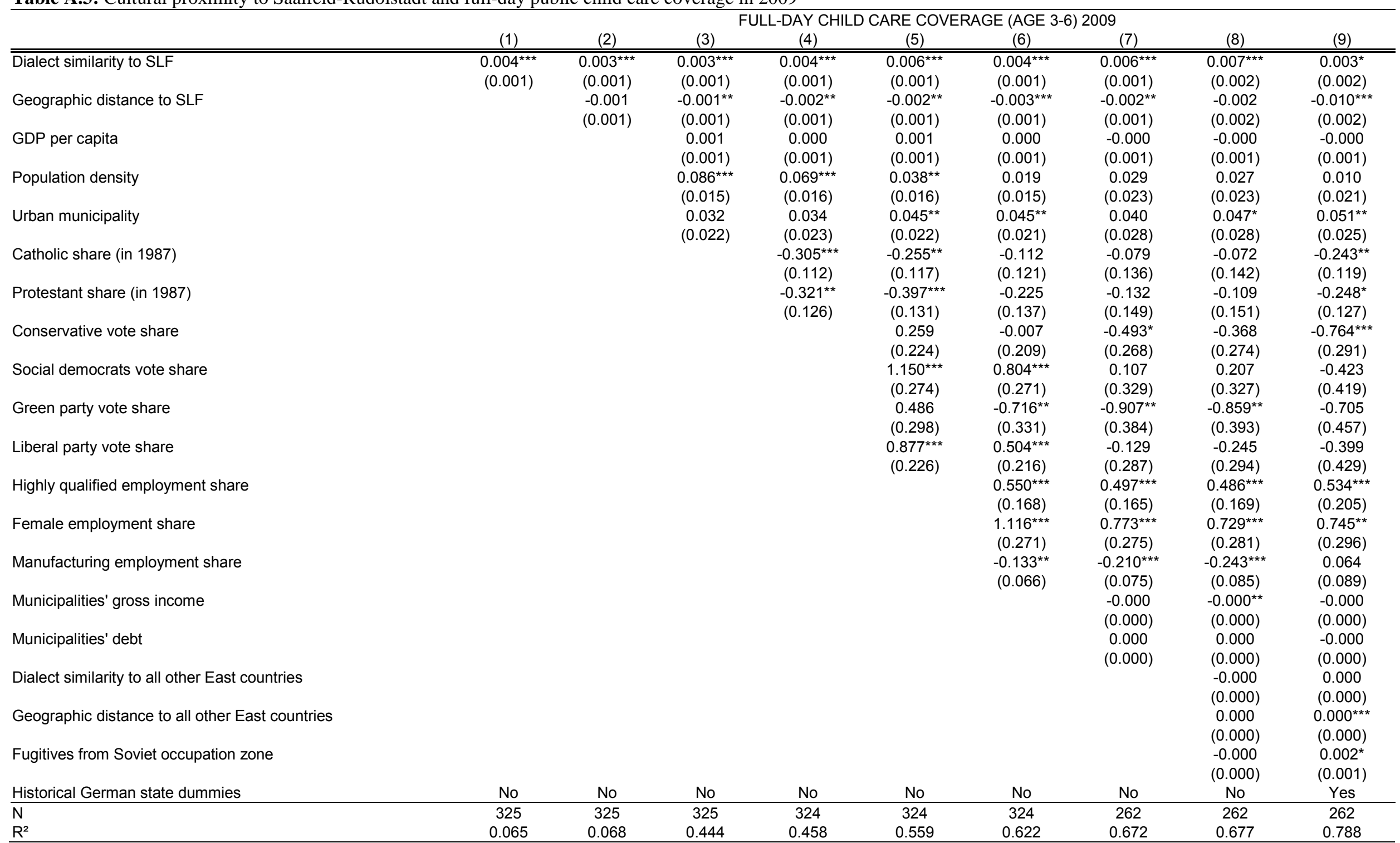

Note: The table shows results of OLS regressions; robust standard errors in parentheses. *** $1 \%$ level of significance, $* * 5 \%$ level of significance, * $10 \%$ level of significance. 
Table A.4a: Individual level data: Descriptives I

\begin{tabular}{|c|c|c|c|}
\hline Variable & & $\mathrm{N}$ & Percent \\
\hline \multicolumn{4}{|c|}{ Public child care attendance } \\
\hline & No & 14,907 & 0.53 \\
\hline & Yes & 13,361 & 0.47 \\
\hline & thereof at age 0 & 24 & 0.02 \\
\hline & at age 1 & 284 & 0.05 \\
\hline & at age 2 & 809 & 0.16 \\
\hline & at age 3 & 1,433 & 0.33 \\
\hline & at age 4 & 2,823 & 0.72 \\
\hline & at age 5 & 3,319 & 0.91 \\
\hline & at age 6 & 3,225 & 0.95 \\
\hline & at age 7 & 1,434 & 0.95 \\
\hline \multicolumn{4}{|c|}{ Migration background } \\
\hline & No & 20,523 & 0.73 \\
\hline & Yes & 7,665 & 0.27 \\
\hline \multicolumn{4}{|c|}{ Single mother } \\
\hline & No & 25,888 & 0.92 \\
\hline & Yes & 2,380 & 0.08 \\
\hline \multicolumn{4}{|c|}{ Urban municipality } \\
\hline & No & 19,105 & 0.68 \\
\hline & Yes & 9,163 & 0.32 \\
\hline
\end{tabular}

Note: The table shows numbers of observations (N) and percentage shares (percent).

Data source: SOEP 1985-2008.

Table A.4b: Individual level data: Descriptives II

\begin{tabular}{lccc}
\hline Variable & $\mathrm{N}$ & Mean & Std.dev. \\
\hline \hline Age & 28,268 & 32.146 & 5.718 \\
Years of schooling & 27,602 & 11.693 & 2.564 \\
Dialect similarity to SLF & 28,268 & 33.319 & 9.605 \\
Geographic distance to SLF (in meter) & 28,268 & 251,177 & 83,547 \\
\hline
\end{tabular}

Note: The table shows numbers of observations (N), mean values (Mean) and standard deviations (Std.dev.).

Data source: SOEP 1985-2008. 
Table A.5: Cultural proximity to Saalfeld-Rudolstadt and public child care attendance on the individual level

\begin{tabular}{|c|c|c|c|}
\hline & \multicolumn{2}{|c|}{$\begin{array}{c}\text { PUBLIC CHILD CARE } \\
(y e s=1, n o=0)\end{array}$} & \multirow{2}{*}{$\begin{array}{c}\text { CHILD'S AGE AT ENTRY } \\
\text { INTO PUBLIC CHILD CARE } \\
\text { West sample } \\
(3) \\
\end{array}$} \\
\hline & $\begin{array}{l}\text { West } \\
(1)\end{array}$ & $\begin{array}{c}\text { East } \\
(2)\end{array}$ & \\
\hline Dialect similarity to SLF & $\begin{array}{l}0.003^{* * *} \\
(0.001)\end{array}$ & $\begin{array}{l}-0.000 \\
(0.001)\end{array}$ & $\begin{array}{c}-0.012^{* *} \\
(0.005)\end{array}$ \\
\hline Geographic distance to SLF & $\begin{array}{c}0.000 \\
(0.000)\end{array}$ & $\begin{array}{l}0.000 \\
(0.000)\end{array}$ & $\begin{array}{l}-0.000 \\
(0.000)\end{array}$ \\
\hline Age & $\begin{array}{c}0.028^{* * *} \\
(0.001)\end{array}$ & $\begin{array}{c}0.016^{* * *} \\
(0.002)\end{array}$ & $\begin{array}{l}-0.009 \\
(0.006)\end{array}$ \\
\hline Years of schooling & $\begin{array}{c}-0.007^{* * *} \\
(0002)\end{array}$ & $\begin{array}{c}0.007 \\
(0.004)\end{array}$ & $\begin{array}{c}-0.060^{* * *} \\
(0.012)\end{array}$ \\
\hline Single mother & $\begin{array}{l}0.192^{* * *} \\
(0.017)\end{array}$ & $\begin{array}{l}0.037^{*} \\
(0.020)\end{array}$ & $\begin{array}{c}-0.294^{* * *} \\
(0.105)\end{array}$ \\
\hline Migration background & $\begin{array}{l}-0.007 \\
(0.009)\end{array}$ & $\begin{array}{l}-0.071 \\
(0.065)\end{array}$ & $\begin{array}{l}0.119^{*} \\
(0.070)\end{array}$ \\
\hline Year dummies & Yes & Yes & Yes \\
\hline $\mathrm{N}$ & 22,587 & 4,937 & 7,657 \\
\hline
\end{tabular}

Note: The table shows the results of OLS estimations on the sample of mothers whose youngest child is not older than seven years old and does not attend a school; standard errors are clustered at the county level. In column (1), the sample is restricted to all mothers living in West Germany, while column (2) restricts the sample to mothers living in East Germany. In column (3), the sample is restricted to a balanced panel of West German mothers whose youngest child is between one and six years old. Probit estimates of columns (1) and (2) yield very similar results. *** $1 \%$ level of significance, $* * 5 \%$ level of significance, $* 10 \%$ level of significance.

Data source: SOEP 1985-2008. 